\title{
Evaluation of a Recombinant Rift Valley Fever Virus Subunit Nucleocapsid Protein as an Immunogen in Mice and Sheep
}

\author{
P. Jansen van Vuren ${ }^{1,2}$, C.T. Tiemessen ${ }^{2,3}$ and J.T. Paweska ${ }^{1,2, *}$
}

${ }^{I}$ Special Pathogens Unit, National Institute for Communicable Diseases of the National Health Laboratory Service, Private Bag X4, Sandringham 2131, South Africa

${ }^{2}$ Division Virology and Communicable Diseases Surveillance, School of Pathology, University of the Witwatersrand, Johannesburg, South Africa

${ }^{3}$ Cell Biology/AIDS Virus Research Unit, National Institute for Communicable Diseases of the National Health Laboratory Service, Private Bag X4, Sandringham 2131, South Africa

\begin{abstract}
The possible role of the most abundant structural protein of Rift Valley fever virus (RVFV), the nucleocapsid protein (NP), in inducing protective immune responses has only been evaluated preliminarily in mice but not in any natural host species. In this study we demonstrate that a soluble recombinant RVFV subunit NP in combination with adjuvants (ISA50, Alhydrogel, TiterMax Gold or SaponinQ) is highly immunogenic in mice and sheep but the level of clinical protection and virus replication in mice after lethal challenge was dependent on the adjuvant used. Immunization with NP in combination with Alhydrogel conferred $100 \%$ protection against morbidity, mortality and viral replication in mice, but sterilizing immunity could not be achieved in sheep with any NP/adjuvant combinations used. Although this is the first study showing that sterilizing immunity can be elicited in mice immunized with a RVFV subunit nucleocapsid protein, our findings seem to suggest that mice might not be the best animal model for studying the protective ability of RVF subunit vaccines. The results of our study also emphasize the importance of adjuvant selection when evaluating subunit RVF vaccines.
\end{abstract}

Keywords: Rift Valley fever virus, nucleocapsid, adjuvants, mice, sheep, immunization.

\section{INTRODUCTION}

Rift Valley fever (RVF) is an emerging mosquito-borne zoonosis with severe health and socio-economic impacts [1, 2] caused by RVF virus (RVFV), a member of the Phlebovirus genus in the Bunyaviridae family [3]. Competent RVFV mosquito vectors are widespread outside the virus' current geographic range causing fears that it might spread to previously RVFV naïve regions [4-7]. The RVFV genome comprises three segments (large, medium, and small) of singlestranded RNA, and is in the negative-sense, except for the small (S) segment which consists of ambisense RNA. The latter codes for the nucleocapsid $(\mathrm{N})$ protein and a nonstructural protein (NSs) $[8,9]$. The $\mathrm{N}$ protein is highly conserved and the most immunodominant viral protein in the Bunyaviridae family [10-13] inducing rapid production of high levels of anti-NP humoral antibodies in infected animals and humans $[14,15]$.

Vaccination of livestock in RVF endemic areas would be the most practical way of preventing the disease in animals and its spread to humans. The modified live Smithburn strain was shown to induce lifelong protective immunity but its use

*Address correspondence to this author at the Pathogens Unit, National Institute for Communicable Diseases of the National Health Laboratory Service, Private Bag X4, Sandringham, 2131, South Africa; Tel: +27 11386 6382; Fax: +27 11882 3741;

E-mail: januszp@nicd.ac.za, paweska.janusz@gmail.com is limited due to abortogenic and teratogenic properties in pregnant ewes, inadequate immunogenicity in cattle, and potential safety problems related to risks of incomplete inactivation, and reversion to virulence. The formalin-inactivated vaccines do not induce durable immunity thus necessitating annual booster vaccinations [16-18] of which administration during long inter-epizootic periods, but also due to unpredictable occurrence of RVF outbreaks, might be difficult to implement. Recent advances include development of attenuated recombinant RVFV strains by reverse genetics [19], RVF virus-like particles [20, 21], virus-vectors expressing RVFV genes [22-25], DNA plasmid vaccines [26, 27] and recombinant subunit immunogens [22, 24, 28]. Recombinant RVF viruses with deletions in the non-structural genes of the small (S) and medium (M) segments were highly attenuated and conferred complete protection against lethal challenge in the rat model [19]. Modified RVFV strains, however, carry the risk of being spread by mosquitoes and the possibility of recombination and reversion to virulence. Immunization of mice with RVF virus-like particles (VLP) resulted in virusneutralizing antibody responses and protection from subsequent lethal RVFV-challenge [20]. Gene gun vaccination with DNA plasmids expressing RVFV glycoproteins induced full [27] or partial protection [26], whereas vaccination with a DNA plasmid expressing the nucleocapsid protein gave only partial protection. A recombinant vaccinia virus containing glycoprotein genes [22], a recombinant lumpy skin 
disease virus vector expressing RVFV glycoproteins [24, 25] and a Sindbis virus replicon vector expressing $\mathrm{Gn}, \mathrm{Gc}$ and NSm proteins [23] induced protection against RVFV challenge in mice, or mice and sheep. The use of other viruses as vaccine-vectors in regions where the wild-type viruses are endemic, however, might be problematic because of possible background immunity. Bacterially expressed recombinant subunit glycoproteins [22, 24, 28] were shown to induce varying levels of protection against RVFV challenge.

Recombinant protein subunits are generally weak immunogens $[29,30]$ and require administration with adjuvants to enhance their immunogenicity [31]. Adjuvants promote the uptake of antigens by antigen presenting cells (APC), contribute to the delivery of antigen to lymph nodes, and stimulate cytokine release or expression of co-stimulatory signals on APC which are needed to prime T helper cells for B cell proliferation and induction of cytotoxic T lymphocytes [29, 32]. Some of the more commonly tested and/or used adjuvants are saponins, alum and water-in-oil adjuvants. Saponin adjuvant, a surface active agent isolated from the Chilean Soap bark tree (Quillaja saponaria), modulates humoral (Th2) as well as cellular immunity (Th-1) and bias immune responses towards the Th- 1 phenotype and can induce strong CD8+ cytotoxic T-cell responses $[29,33,34] . \mathrm{CD}^{+} \mathrm{T}$ cells are able to kill virus-infected cells by inducing apoptosis, and kill infected cells directly in the lymph nodes draining infected sites [35]. Aluminium hydroxide gel (Alhydrogel), commonly known as alum allows for a depot effect at the inoculation site [29], and has also been found to promote the release of IL-4 which results in the increased expression of major histocompatibility class II (MHC II) molecules on monocytes, consequently increasing antigen uptake by APC $[36,37]$. Alum does not induce the cytokines interleukin-2 (IL-2) and interferon-gamma (IFN- $\gamma$ ) which are involved in the Th-1 type response, but might directly activate nuclear factor kappa-beta $(\mathrm{NF}-\mathrm{\kappa B})$, that is involved in regulating the cellular response to infections [37]. The NF- $\kappa B$ is required for positive selection of memory $\mathrm{CD}^{+} \mathrm{T}$ cells $[38,39]$. Montanide ISA50 adjuvant is based on a mannide oleate in mineral oil solution, and contributes to the establishment of a depot effect, transportation of emulsified antigen to distant sites through the lymphatic system, and interaction with mononuclear cells such as APC. ISA50 has been shown to direct the immune response against specific antigens towards the Th-2 type response, involved in humoral immunity [29]. TiterMax Gold (TMG) is a water-in-oil adjuvant that contains a metabolizable oil (squalene), sorbitan monooleate and an immunostimulatory copolymer. It has been shown to induce mixed Th-1/Th-2 responses against specific antigens, but these responses were more directed towards Th-2, indicating humoral immunity [33]. The different mechanisms by which adjuvants enhance different types of immune responses stress the importance of adjuvant selection for vaccine formulations.

In a recent study, a bacterially expressed RVFV recombinant nucleocapsid protein, together with Quil-A adjuvant, was used to immunize BALB/c mice which were subsequently challenged with a lethal dose of RVFV. A protection rate of $60 \%$ was achieved but replication of virus, or lack thereof, was not evaluated in surviving or dead mice [24]. Immunization of animals with recombinant subunit $\mathrm{N}$ proteins from related viruses in the Bunyaviridae family, Dobrova and Hantaan did, however, result in complete protection against viral challenge [40-42]. Recently we expressed a recombinant RVFV nucleocapsid protein, using a bacterial system, in a completely soluble form which was subsequently shown to efficiently bind antibodies from various species [15, 43-46].

In this study we expanded the earlier observations [24] by using a soluble RVFV recNP [15] together with four adjuvants to immunize mice, evaluation of its ability to induce protective immune responses not only by measuring survival ratios but also reduction of viral replication in mouse organs. Further we evaluated the immunogenicity of the recNP antigen, combined with the same adjuvants, in a host animal model and the ability of anti-recNP responses to limit viral replication in sheep after RVFV challenge. To our knowledge this is the first study showing the immunogenicity of a recombinant subunit RVFV NP in a host animal model.

\section{MATERIALS AND METHODOLOGY}

\section{Cells and Virus}

Vero cells were cultivated in Eagles Minimal Essential Medium (EMEM) (BioWhitaker, MD, USA) containing LGlutamine, non-essential amino acids, antibiotics (100 IU penicillin, $100 \mu \mathrm{g}$ streptomycin and $0.25 \mu \mathrm{g}$ amphotericin B) and $10 \%$ foetal bovine serum (Gibco) and maintained at $37^{\circ} \mathrm{C}$ in $5 \% \mathrm{CO}_{2}$ incubator. The SPU22/118 KEN 07 strain of RVFV was isolated from a RVF human case during the 2007 Kenyan epidemic [47]. Second passage of the virus, propagated in Vero cells, was used for the challenge.

\section{Bacterial Expression of Recombinant RVFV N Protein}

Bacterial expression and purification of the recombinant $\mathrm{N}$ protein was carried out as described previously [15]. Briefly, the $\mathrm{N}$ gene was cloned into the pET32(a)+ expression vector (Novagen, Germany) from RNA of the RVFV Zim688/78 strain, and subsequently expressed in Origami(DE3) cells (Novagen) after induction with isopropyl $\beta$ D-1-thiogalactopyranoside (IPTG, Roche, Germany) for $4 \mathrm{~h}$ at $37^{\circ} \mathrm{C}$. Cells were lysed with Bugbuster reagent and Lysonase (Novagen), and recombinant fusion protein containing a $6 \mathrm{xHis}$ tag subsequently purified from the soluble fraction using Protino Ni-chelate columns (Machery-Nagel). E. coli background proteins were not detectable in the purified end product [results shown in 15].

\section{Mouse Immunization}

Four-week old female BALB/c inbred mice were used. The low dose vaccination group (M-I) consisted of 48 mice divided in 4 sub-groups of 12 mice each which were immunized with a $100 \mu \mathrm{l}$ inoculum containing $35 \mu \mathrm{g}$ RVFV recNP in combination with ISA-50 adjuvant (Seppic, France), TiterMax-Gold adjuvant (TMG)(Sigma, U.S.A.), Alhydrogel (Sigma) or SaponinQ $(60 \mu \mathrm{g}$, Sigma), respectively. The high dose vaccination group (M-II) consisted of 48 mice which were subdivided as the M-I group but immunized with $200 \mu 1$ of inoculum containing $70 \mu \mathrm{g}$ of recNP in combination with the adjuvants as described above. The neat recNP group (M$\mathrm{N})$ consisted of 12 mice immunized with $70 \mu \mathrm{g}$ recNP in PBS buffer. The adjuvant control group consisted of 36 mice di- 
vided in 3 sub-groups of 12 mice each which were respectively inoculated only with ISA-50, Alhydrogel or SaponinQ. Note: because of immunization error a fourth adjuvant control subgroup (TiterMax Gold) was excluded from the study. The placebo control group consisted of 12 mice which were inoculated with PBS buffer. All mice were inoculated subcutaneously (s.c) using $1 \mathrm{ml}$ syringes and 25 gauge needles to mimic the natural route of RVFV infection. All animals received identical booster immunizations at 14 days after the initial immunization. A mouse from each group was sacrificed and heart-bled every seven days after primary and booster immunizations to monitor immune responses. Adjuvants ISA50, TMG and Alhydrogel were used as suggested by the manufacturers. The dose of SaponinQ adjuvant (Sigma, U.S.A.) was determined by titration in $\mathrm{BALB} / \mathrm{c}$ mice and by selecting the highest non-toxic dose at $60 \mu \mathrm{g}$ (results not shown). The selection of recNP doses were determined by recNP concentration and feasible mouse inoculum sizes.

\section{Sheep Immunization}

Sheep were pre-screened for antibodies against RVFV using enzyme linked immunosorbent assay (ELISA). Twenty three adult female Dorper cross sheep, younger than one year, were used. The sheep were divided into groups as described in Table 1. All sheep were inoculated subcutaneously (s.c.) using $1 \mathrm{ml}$ syringes and 25 gauge needles to mimic the natural route of RVFV infection. All animals received identical booster inoculations as described in Table 1. Serum was collected at regular intervals, as indicated in Table $\mathbf{1}$, for immune response monitoring.

\section{IMMUNE RESPONSE MONITORING AFTER IM-} MUNIZATION

\section{Indirect IgG ELISA}

The indirect ELISA was done as described previously [15]. Briefly, immunoplates (Maxisorb, Nunc, Denmark) were coated with RVFV recNP antigen at a dilution of 1:2000 $(0.5 \mu \mathrm{g} / \mathrm{ml})$ in Carbonate-Bicarbonate buffer $(\mathrm{pH} 9.6)$ and incubated overnight at $4^{\circ} \mathrm{C}$. After washing three times with a washing buffer consisting of phosphate buffered saline (PBS) pH7.2 and $0.1 \%$ Tween-20, the plates were blocked with $200 \mu \mathrm{l}$ of $10 \%$ fat free milk powder ("Elite", Clover SA, Pty, Ltd.) in PBS at $37^{\circ} \mathrm{C}$ for $1 \mathrm{~h}$ and then washed as before. Test sera were diluted 1:400 in diluent buffer consisting of $2 \%$ fat free milk powder in PBS, $100 \mu 1$ added to each well and incubated for $1 \mathrm{~h}$ at $37^{\circ} \mathrm{C}$. Samples were tested in duplicate. After washing as before, $100 \mu \mathrm{l}$ of goat antimouse IgG horseradish peroxidase (HRPO) $(\mathrm{H}+\mathrm{L})$ at 1:2000 dilution (for mice) or recombinant Protein G HRPO (Zymed Laboratories, Invitrogen, U.S.A.) at 1:6000 dilution (for sheep) was added to the plates. After $1 \mathrm{~h}$ incubation at $37^{\circ} \mathrm{C}$ plates were washed as before and $100 \mu 1$ of 2,2'azinodiethylbenzthiazoline sulfonic acid (ABTS) (KPL Laboratories, Inc., USA) added to each well. After $30 \mathrm{~min}$ incubation in the dark the reaction was stopped by the addition of $100 \mu \mathrm{l}$ of $1 \%$ sodium dodecyl sulfate (SDS) to each well. Optical density (OD) was determined at $405 \mathrm{~nm}$ and the results expressed as the mean OD value for the duplicates tested. The positive control serum was generated as described previously [48] by infecting eight sheep with the AR 20368 RVFV strain and pooling highly reactive sera from collections made between day 1 and 72 post-infection. The negative control serum was serum pooled from six animals shown to be negative in the virus neutralization test as described previously [48].

\section{Virus Neutralization Test}

In addition, a virus neutralization test (VNT) was performed on sera collected from mice and sheep after immunization to measure neutralizing ability of these sera. The VNT was performed as described previously [48] by titrating sera from a 1:10 dilution in two-fold dilutions. The titer is expressed as the reciprocal of the serum dilution that inhibited $\geq 75 \%$ of the viral cytopathic effect (CPE).

Table 1. Group Assignments, Inoculums and Sheep Immunization and Sampling Schedule

\begin{tabular}{|c|c|c|c|c|c|}
\hline $\begin{array}{l}\text { Group } \\
\text { Number }\end{array}$ & $\begin{array}{l}\text { Number of } \\
\text { Sheep }\end{array}$ & $\begin{array}{l}\text { RVFV recNP } \\
\text { Dose }(\mu \mathrm{g})\end{array}$ & Adjuvant/Inoculum & Immunization Schedule & $\begin{array}{c}\text { Blood Collection } \\
\text { Schedule (Day After } \\
\text { Immunization/Booster) }\end{array}$ \\
\hline 1a & $\mathrm{n}=2$ & 175 & ISA50 & \multirow{8}{*}{$\begin{array}{c}\text { Day } 0 \text { (initial) } \\
\text { Day } 21 \text { (booster) }\end{array}$} & \multirow{10}{*}{$\begin{array}{c}\text { Day 0, Day 14, Day } 26 \\
\text { Day } 14 \text { after booster }\end{array}$} \\
\hline $1 \mathbf{b}$ & $\mathrm{n}=2$ & 350 & ISA50 & & \\
\hline $2 a$ & $\mathrm{n}=2$ & 175 & Alhydrogel & & \\
\hline $2 b$ & $\mathrm{n}=2$ & 350 & Alhydrogel & & \\
\hline 3a & $\mathrm{n}=2$ & 175 & TiterMax Gold® & & \\
\hline $3 \mathbf{b}$ & $\mathrm{n}=2$ & 350 & TiterMax Gold ${ }^{\circledR}$ & & \\
\hline $4 a$ & $\mathrm{n}=2$ & 175 & SaponinQ & & \\
\hline $4 b$ & $\mathrm{n}=2$ & 350 & SaponinQ & & \\
\hline 5 & $\mathrm{n}=4$ & 0 & $\begin{array}{c}\text { ISA50, Alhydrogel, TiterMax } \\
\text { Gold® or SaponinQ }\end{array}$ & \multirow{2}{*}{$\begin{array}{c}\text { Day } 0 \text { (initial mock) } \\
\text { Day } 21 \text { (mock booster) }\end{array}$} & \\
\hline 6 & $\mathrm{n}=3$ & 0 & PBS & & \\
\hline
\end{tabular}




\section{RVFV CHALLENGE}

\section{Mice}

After the immunization period, 5 to 7 animals from each group were challenged with RVFV on day 32 after the booster immunization. Mice were inoculated s.c. with a 100 $\mu 1$ inoculum containing $10^{7.0} \mathrm{TCID}_{50} / \mathrm{ml}$ RVF challenge virus, and after challenge examined twice daily for signs of clinical illness including loss of appetite and consequent weight loss, scruffy coat, decreased alertness, decreased mobility, loss of balance, shallow and irregular breathing, and hunched posture. Animals displaying severe illness were euthanized and organs collected. Organs were also collected at regular intervals from healthy, sick and dead mice to monitor viremia. Surviving mice were monitored for 22 days post infection. A control group was mock inoculated with Eagle's minimum essential medium (EMEM) free of the virus.

\section{Sheep}

All sheep were challenged s.c. with $2 \mathrm{ml}$ challenge virus ( $1 \mathrm{ml}$ on both sides of the neck). Sheep were challenged at different times as follows: one sheep from each sub-group (group 1a,b - 4a,b), all sheep from group five and one sheep from group six were challenged on day 37 after the booster immunization (total $=13$ sheep); the remaining sheep were challenged on day 168 after the booster immunization (total $=10$ sheep). Sheep were monitored daily for the first two weeks after challenge and blood taken daily for the first seven days, and at regular intervals thereafter to monitor viremia and immune responses until day 70 .

\section{IMMUNE RESPONSE MONITORING AFTER RVFV CHALLENGE}

Immune responses in sheep after challenge were monitored by IgM capture ELISAs as described previously [48]. A virus neutralization test (VNT) was performed as described above. Means and standard deviations for IgM ELISA readings and VNT titres were based on data from minimum two animals per group.

\section{PASSIVE IMMUNIZATION OF MICE WITH ANTI- RECNP IMMUNE SERA}

The ability of anti-N antibodies to passively confer immunity in mice was evaluated using polyclonal antisera generated in sheep, rabbits and mice. Mice were immunized with recNP as described earlier, and antisera from different recNP/adjuvant experimental groups were respectively pooled before testing. Polyclonal anti-N antisera in rabbits and sheep were produced as described previously [43]. All polyclonal sera were mixed to final dilution of 1:10 with Vero-derived virus preparation containing $10^{7.0} \mathrm{TCID}_{50} / \mathrm{ml}$ of the 2007 Kenya RVFV isolate, and the mixture incubated at $37^{\circ} \mathrm{C}$ for $30 \mathrm{~min}$ before inoculation. As controls, sera from naïve sheep, rabbits and mice were mixed identically with RVFV. To control the effects of non-related compounds in serum, sterile PBS was mixed to a 1:10 with the virus. A total of $42 \mathrm{BALB} / \mathrm{c} 3-4$ weeks old female mice, were divided into groups of 6 animals each and inoculated s.c. with $200 \mu 1$ of the following mixtures: a) virus and mouse anti-recNP, b) virus and sheep anti-recNP, c) virus and rabbit anti-recNP, d) virus and naive mouse serum, e) virus and naïve sheep serum, f) virus and naïve rabbit serum, and g) virus and PBS. Mice were examined twice daily clinically and those displaying severe signs of illness were euthanized. Surviving mice were monitored for 22 days post infection.

\section{VIRUS TITRATIONS}

Mouse liver and kidney tissues were homogenized as $10 \%(\mathrm{w} / \mathrm{v})$ suspensions in EMEM containing L-Glutamine, non-essential amino acids, antibiotics (100 IU penicillin, 100 $\mu \mathrm{g}$ streptomycin and $0.25 \mu \mathrm{g}$ amphotericin B). After centrifugation at $3000 \mathrm{x} \mathrm{g}, 4^{\circ} \mathrm{C}$ for 15 minutes, supernatants were collected and stored at $-70^{\circ} \mathrm{C}$ until tested.

Virus titrations of mouse tissue homogenates and sheep sera collected after challenge were performed as described previously [49]. Briefly, four $100 \mu$ l replicates of 10 -fold dilutions $\left(10^{-1}\right.$ to $\left.10^{-8}\right)$ of homogenates or sera were transferred into flat bottomed 96-well cell culture microplates (Nunc) and equal volumes of Vero cell suspension in EMEM containing $2 \times 10^{5}$ cells $/ \mathrm{ml}, 8 \%$ FBS and antibiotics were added. The plates were incubated at $37^{\circ} \mathrm{C}$ in $\mathrm{CO}_{2}$ and observed microscopically for cytopathic effects (CPE) for 10 days post inoculation. Virus titers, calculated by the Kärber method [50] were expressed as median tissue culture infectious dose $\left(\mathrm{TCID}_{50}\right)$ per $\mathrm{ml}$ of serum or gram of tissue. Means and standard deviations from the means were determined based on two or more animals per group.

\section{REAL TIME REVERSE TRANSCRIPTASE PCR (QRT-PCR)}

Real time PCR was performed only on mouse tissue homogenates that yielded negative results by virus titration. Viral RNA was extracted from $140 \mu$ l of tissue homogenates using the QIAmp ${ }^{\circledR}$ Viral RNA Kit (QIAgen, Germany) according to the instructions of the manufacturer. The qRTPCR was performed as described previously [49]. Briefly, amplifications were carried out in $20 \mu 1$ reaction mixtures containing $5 \mu \mathrm{l}$ of the extracted vRNA using the LightCycler RNA Amplification Hybprobe kit (Roche, Germany) and the Roche LightCycler instrument. Primers and a labeled probe targeting the G2 glycoprotein gene of RVFV were used.

\section{STATISTICAL METHODS}

Survival proportions in immunized mice versus control mice after challenge were compared using the Fisher exact test (Soper online statistics calculator) [51]. Viral load results in mouse organs are based on TCID $_{50}$ titrations of virus in tissues from three or more animals and given as means. P-values lower than 0.01 were considered to be significant.

The significance of differences between immune responses and viremia in sheep was confirmed using the Fisher F-test giving a two-tailed probability value (Excel, Microsoft Office). P-values lower than 0.01 were considered to be significant. Mean values and standard deviations from the means were calculated using at least two sheep per group.

\section{RESULTS}

\section{Immunogenicity of the recNP}

All recNP/adjuvant combinations induced detectable anti-recNP IgG responses by day seven after a single immu- 
nization of mice (Fig. 1) with similarly increasing levels over time. The recNP without adjuvant induced a weaker but still detectable IgG response. None of the control mice (PBS or adjuvant controls) developed any antibodies against the recNP. Anti-recNP immune sera from mice were not able to neutralize the virus in-vitro (results not shown).
All sheep immunized with recNP combined with adjuvants produced detectable anti-NP IgG responses by day 14 after the first immunization (Fig. 2). The anti-NP antibody levels of immunized sheep were consistently equal to or higher than that in experimentally infected sheep (dotted vertical line in Fig. 2). The second immunization of all sheep

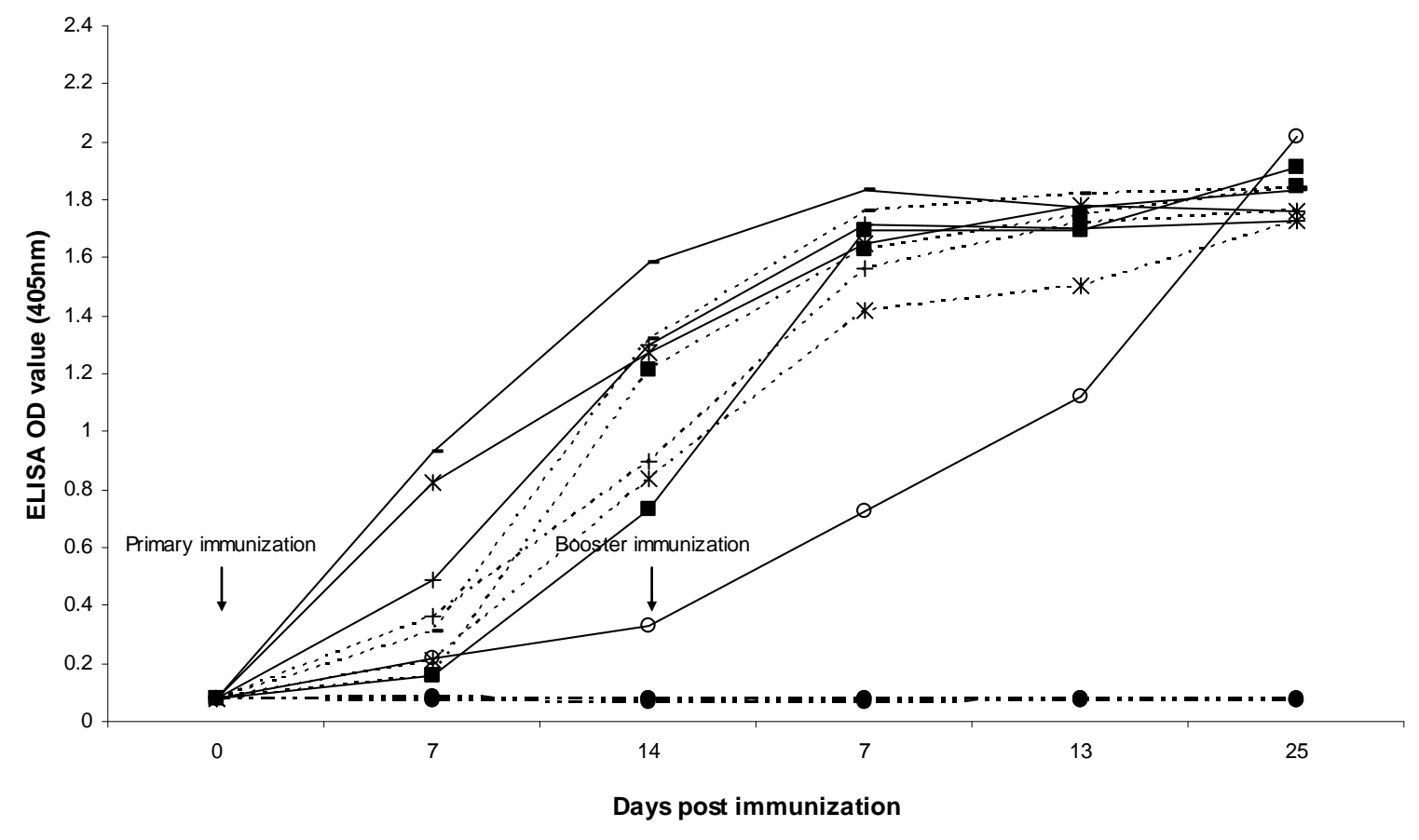

Fig. (1). Anti-RVFV recNP IgG responses in immunized and control mice. Low dose $(35 \mu \mathrm{g}$ recNP) mice are indicated by dotted lines (---) and high dose $(70 \mu \mathrm{g}$ recNP) mice by solid lines (-). Adjuvant combinations are indicated as ISA50 (x), TiterMax Gold (匹), Alhydrogel (+), SaponinQ (-) and recNP without adjuvant (o). Adjuvant and PBS placebo mice are indicated by dotted lines and $\bullet$.

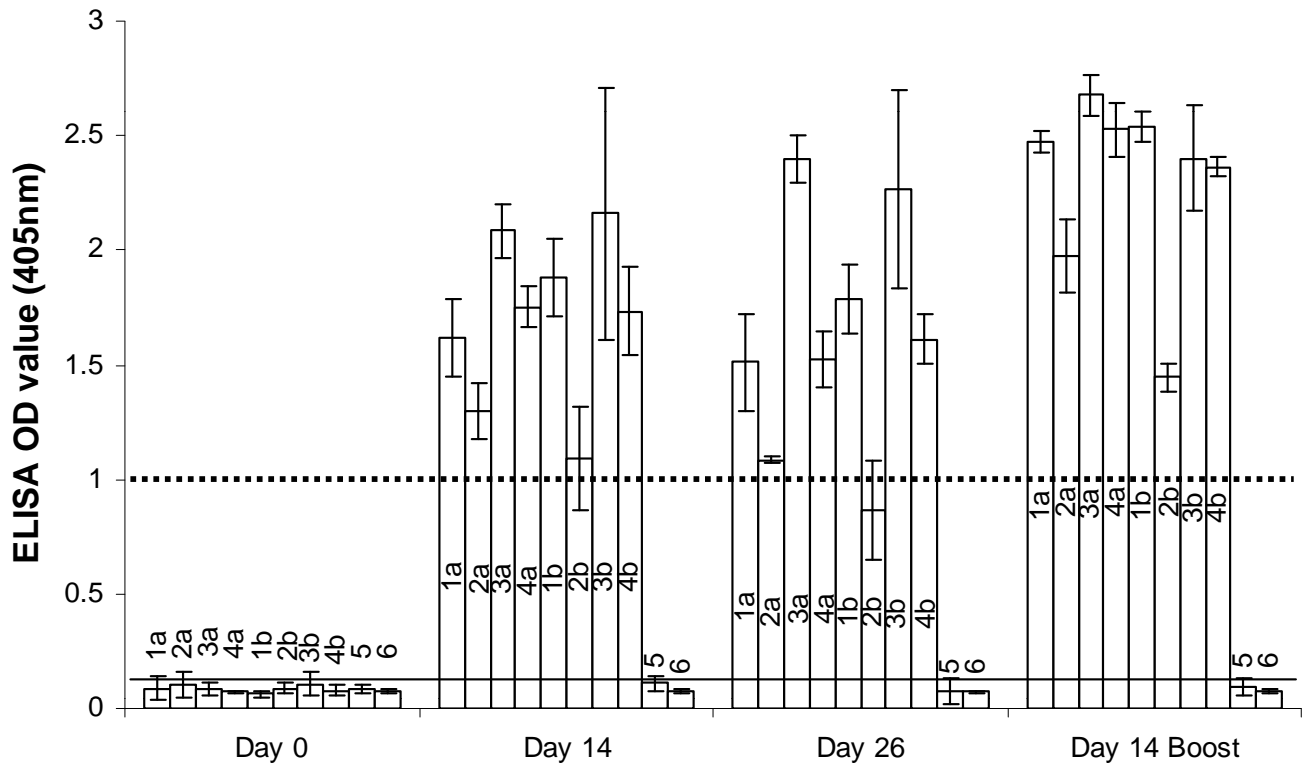

Fig. (2). Average anti-NP responses in sheep after recNP first and booster immunizations; error bars indicate standard deviations from the means. 1a) $175 \mu \mathrm{g}$ recNP/ISA50 $(\mathrm{n}=2)$; 2a) $175 \mu \mathrm{g}$ recNP/Alhydrogel $(\mathrm{n}=2)$; 3a) $175 \mu \mathrm{g}$ recNP/TiterMax Gold (n=2); 4a) 175 $\mu \mathrm{g}$ recNP/SaponinQ $(n=2) ; 1 b) 350 \mu \mathrm{g}$ recNP/ISA50 $(n=2) ; 2 b) 350 \mu \mathrm{g}$ recNP/Alhydrogel $(n=2) ; 3 b) 350 \mu \mathrm{g}$ recNP/TiterMax Gold $(\mathrm{n}=2)$; $4 \mathrm{~b})$ $350 \mu \mathrm{g}$ recNP/SaponinQ; 5) Adjuvant controls $(\mathrm{n}=4)$ and 6) PBS controls $(\mathrm{n}=3)$. The vertical dotted line indicates the average OD reading for a high positive control serum. The solid vertical line indicates the average OD reading for a negative control serum. 
had the desired effect of boosting humoral immune responses. The combination of recNP with Alhydrogel (group $2 \mathrm{a}-\mathrm{b})$ was the least immunogenic but still induced strong responses compared to the positive control. The larger recNP dose $(350 \mu \mathrm{g})$ did not induce significantly stronger responses in any of the immunized groups when compared to the lower dose $(175 \mu \mathrm{g})$ with the same adjuvants: recNP/ISA50 (Group $1 \mathrm{a}-\mathrm{b}$, Fischer F-test $\mathrm{p}=0.915$ ), recNP/Alhydrogel (Group $2 \mathrm{a}-\mathrm{b}, \mathrm{p}=0.638$ ), recNP/TiterMax Gold (Group 3a-b, $\mathrm{p}=$ 0.902 ) and recNP/SaponinQ (Group $4 \mathrm{a}-\mathrm{b}, \mathrm{p}=0.930$ ). Because the dose of recNP did not have a significant impact on the strength of the humoral responses, groups that were immunized with the same recNP/adjuvant combination, regardless of dose, were grouped together for the RVFV challenge experiment. As expected, the adjuvant and PBS control groups did not develop any anti-NP responses during the immunization period. The immune responses elicited by recNP immunization were not neutralizing (results not shown).

\section{PROTECTION OF MICE AGAINST RVFV CHAL- LENGE}

All mice in the adjuvant and PBS placebo control groups died or developed severe symptoms by day six postinfection. In contrast, clinical signs in all unprotected immunized animals were delayed by four to nine days as com- pared to controls (Table 2). Clinical signs in sick animals included loss of appetite and consequent weight loss, scruffy coat, decreased alertness, decreased mobility, loss of balance, shallow and irregular breathing, and hunched posture. Only immunization with 35 and $70 \mu \mathrm{g}$ recNP/Alhydrogel, and $70 \mu \mathrm{g}$ recNP/SaponinQ yielded significant protection from disease/death $(\mathrm{p} \leq 0.01$, Fischer exact test) (Table 2$)$. The best protection (100\%) was achieved after immunization with both doses of recNP combined with Alhydrogel, as well as immunization with $70 \mu \mathrm{g}$ recNP/SaponinQ. The mock inoculated mice (with EMEM free of virus) did not develop any clinical signs during the experiment. Despite full or partial clinical protection resulting from immunization, the challenge virus replicated in most immunized mice, but to lower levels than in adjuvant and PBS control mice. Replication of virus could not be shown in liver and kidney tissues from mice immunized with $70 \mu \mathrm{g}$ recNP/Alhydrogel, either by virus isolation or qRT-PCR. Table $\mathbf{3}$ summarizes viral load data in mice during the acute period of infection (day $1-6)$.

\section{PASSIVE IMMUNITY BY ANTI-RECNP IMMUNE SERA}

Anti-recNP immune sera did not neutralize virus in-vivo. No significant decrease in mortality/morbidity could be shown in any of the groups: al virus and mouse anti-recNP

Table 2. Mouse Survival Rates

\begin{tabular}{|c|c|c|c|}
\hline Group & Survivors/Total (\% Survival $)^{a}$ & Morbidity / Mortality (Day Post Infection) & Significance of Protection ${ }^{c}$ \\
\hline $35 \mu \mathrm{g} \mathrm{recNP} / \mathrm{ISA50}$ & $4 / 6(67 \%)$ & $\begin{array}{l}1 \text { (Day 10) } \\
1 \text { (Day 15) }\end{array}$ & $\mathrm{p}=0.0303$ \\
\hline $70 \mu \mathrm{g}$ recNP/ISA50 & $2 / 5(40 \%)$ & $\begin{array}{l}2 \text { (Day } 10) \\
1 \text { (Day } 15)\end{array}$ & $\mathrm{p}=0.1818$ \\
\hline $35 \mu \mathrm{g} \mathrm{recNP} / \mathrm{TMG}$ & $4 / 7(57 \%)$ & $\begin{array}{l}2 \text { (Day } 10) \\
1 \text { (Day 14) }\end{array}$ & $\mathrm{p}=0.0489$ \\
\hline $70 \mu \mathrm{g}$ recNP/TMG & $3 / 5(60 \%)$ & 2 (Day 15) & $\mathrm{p}=0.0606$ \\
\hline $35 \mu \mathrm{g}$ recNP/Alhydrogel & $6 / 6(100 \%)$ & No morbidity / mortality & $\mathrm{p}=0.0011$ \\
\hline $70 \mu \mathrm{g}$ recNP/Alhydrogel & $5 / 5(100 \%)$ & No morbidity / mortality & $\mathrm{p}=0.0022$ \\
\hline $35 \mu \mathrm{g}$ recNP/Saponin $Q$ & $4 / 6(67 \%)$ & 2 (Day 10) & $\mathrm{p}=0.0303$ \\
\hline $70 \mu \mathrm{g}$ recNP/Saponin $Q$ & $6 / 6(100 \%)$ & No morbidity / mortality & $\mathrm{p}=0.0011$ \\
\hline $70 \mu \mathrm{g}$ recNP & $1 / 6(17 \%)$ & $\begin{array}{l}1 \text { (Day } 7) \\
2 \text { (Day } 8) \\
2 \text { (Day } 9)\end{array}$ & $\mathrm{p}=0.500$ \\
\hline $\begin{array}{l}\text { Adjuvant control group } \\
\text { ISA50 }\end{array}$ & $0 / 5(0 \%)$ & $\begin{array}{l}4 \text { (Day 3) } \\
1 \text { (Day 6) }\end{array}$ & No protection \\
\hline $\begin{array}{l}\text { Adjuvant control group } \\
\text { Alhydrogel }\end{array}$ & $0 / 5(0 \%)$ & 5 (Day 2) & No protection \\
\hline $\begin{array}{l}\text { Adjuvant control group } \\
\text { SaponinQ }\end{array}$ & $0 / 6(0 \%)$ & $\begin{array}{l}2 \text { (Day } 3) \\
1 \text { (Day 4) } \\
3 \text { (Day 6) }\end{array}$ & No protection \\
\hline Placebo control group (PBS) & $0 / 6(0 \%)$ & $\begin{array}{l}5 \text { (Day 3) } \\
1 \text { (Day 4) }\end{array}$ & No protection \\
\hline
\end{tabular}

${ }^{a}$ Survivors/total number of mice ratio. (\%) indicates percentage survival.

${ }^{\mathrm{b}}$ Indicates the number of mice that died or were euthanized because of severe morbidity, with the days post infection indicated in brackets.

'Significance of protection calculated using Fisher's Exact test. P-values $\leq 0.01$ were considered significant. 
(survival 1/6, 17\%, Fischer's exact test $\mathrm{p}=0.500$ ), b $\backslash$ virus and sheep anti-recNP (survival 2/6,33\%, $\mathrm{p}=0.227$ ), $\mathrm{c} \backslash$ virus and rabbit anti-recNP (survival 0/6, 0\%, $\mathrm{p}=1.000$ ), $\mathrm{d} \backslash$ virus and naive mouse serum (survival 0/6,0\%), el virus and naïve sheep serum (survival 0/6, 0\%) $\mathrm{f} \backslash$ virus and naïve rabbit serum (survival $0 / 6,0 \%$ ), and $\mathrm{g} \backslash$ virus and PBS (survival $0 / 6$, $0 \%)$.

\section{IMMUNE RESPONSES IN SHEEP AFTER RVFV CHALLENGE}

Because the dose of recNP did not have a significant impact on the strength of the humoral responses, groups that were immunized with the same recNP/adjuvant combination, regardless of dose, were grouped together for the RVFV challenge experiment. All adjuvant control sheep were regarded as one group, and all PBS control sheep were regarded as one group, regardless of when they were challenged with RVFV.

The sheep IgM responses after challenge are shown in Fig. (3A) and in Fig. (3B). None of the immunized or control sheep had any detectable RVFV specific IgM antibodies on the days they were challenged. High levels of RVFV specific IgG, however, was detected in all immunized sheep on the days they were challenged, but as expected not in control

Table 3. Viral Load Data in Mice During the Acute Period of Infection (day 1 - 6)

\begin{tabular}{|c|c|c|c|c|}
\hline Group & Organ Tissue & Number of Mice Tested & Mean Viral Load ${ }^{\mathrm{a}}$ & Range $(\text { StDev })^{\text {b }}$ \\
\hline \multirow{2}{*}{ idne recNP/ISA50 } & Liver & 3 & Negative * & No virus detected* \\
\hline & Kidney & 3 & 1.3 & $0.0-4.0(2.3)$ \\
\hline \multirow{2}{*}{$70 \mu \mathrm{g}$ recNP/ISA50 } & Liver & 4 & Negative & No virus detected \\
\hline & Kidney & 4 & Negative * & No virus detected* \\
\hline \multirow{2}{*}{$35 \mu \mathrm{g} \mathrm{recNP} / \mathrm{TMG}$} & Liver & 4 & Negative & No virus detected \\
\hline & Kidney & 4 & 0.9 & $0.0-3.8(1.9)$ \\
\hline \multirow{2}{*}{$70 \mu \mathrm{g} r e c N P / T M G$} & Liver & 3 & Negative $*$ & No virus detected* \\
\hline & Kidney & 3 & Negative * & No virus detected* \\
\hline \multirow{2}{*}{$35 \mu \mathrm{g}$ recNP/Alhydrogel } & Liver & 3 & Negative & No virus detected \\
\hline & Kidney & 3 & 1.3 & $0.0-4.0(2.3)$ \\
\hline \multirow{2}{*}{$70 \mu \mathrm{g}$ recNP/Alhydrogel } & Liver & 3 & Negative & No virus detected \\
\hline & Kidney & 3 & Negative & No virus detected \\
\hline \multirow{2}{*}{$35 \mu \mathrm{g}$ recNP/SaponinQ } & Liver & 4 & 1.0 & $0.0-4.0(2.0)$ \\
\hline & Kidney & 4 & Negative * & No virus detected* \\
\hline \multirow{2}{*}{$70 \mu \mathrm{g}$ recNP/Saponin $Q$} & Liver & 3 & Negative * & No virus detected* \\
\hline & Kidney & 3 & 1.3 & $0.0-3.8(2.2)$ \\
\hline \multirow{2}{*}{$70 \mu g$ recNP } & Liver & 6 & 0.8 & $0.0-4.5(1.8)$ \\
\hline & Kidney & 6 & 3.0 & $0.0-5.3(2.4)$ \\
\hline \multirow{2}{*}{ Adjuvant control group (ISA50) } & Liver & 5 & 3.5 & $0.0-5.3(2.0)$ \\
\hline & Kidney & 5 & 5.0 & $3.8-5.3(0.8)$ \\
\hline \multirow{2}{*}{ Adjuvant control group (Alhydrogel) } & Liver & 5 & 4.5 & $3.8-5.3(0.9)$ \\
\hline & Kidney & 5 & 5.7 & $5.0-6.5(0.6)$ \\
\hline \multirow{2}{*}{ Adjuvant control group (SaponinQ) } & Liver & 6 & 5.3 & $3.8-6.8(1.3)$ \\
\hline & Kidney & 6 & 5.8 & $4.5-6.3(0.7)$ \\
\hline \multirow{2}{*}{$\begin{array}{l}\text { Placebo control group } \\
\text { (PBS) }\end{array}$} & Liver & 6 & 5.9 & $4.0-7.3(1.3)$ \\
\hline & Kidney & 6 & 5.3 & $4.3-6.0(0.6)$ \\
\hline
\end{tabular}

Organs were collected from sick and healthy mice after infection.

${ }^{a}$ Viral loads are indicated as mean $\log _{10} \mathrm{TCID}_{50} / \mathrm{g}$ tissue.

${ }^{\mathrm{b}}$ Range of $\log _{10} \mathrm{TCID}_{50}$ values and standard deviation from the mean.

*Indicates where viral RNA was detected by qRT-PCR in virus negative tissues. 

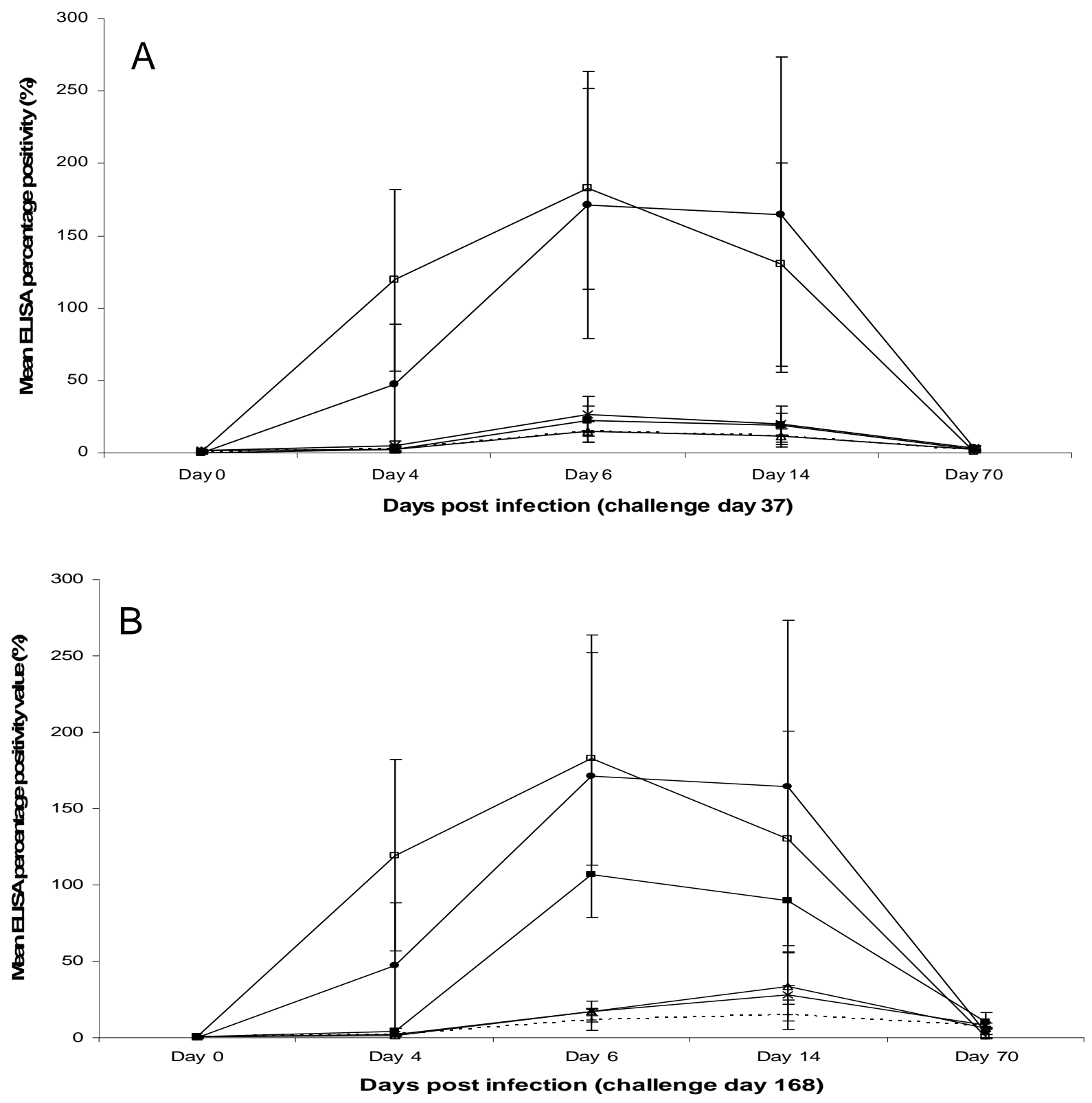

Fig. (3). Mean IgM responses in sheep after RVFV challenge on day 37 (A) or 168 (B). Sheep groups are indicated as recNP/ISA50 (--+--),

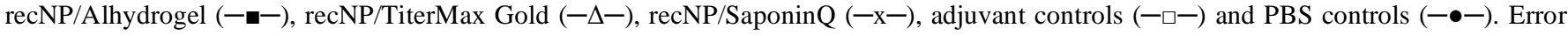
bars indicate standard deviations from the means of two or more sheep per group.

sheep (results not shown). Control sheep developed typical transient IgM responses after RVFV challenge. All immunized sheep developed lower IgM responses after challenge when compared to control sheep, except the recNP/ Alhydrogel immunized sheep that were challenged on day 168 , which developed elevated IgM responses when compared to other immunized sheep. Incidentally, these recNP/Alhydrogel immunized sheep had decreased RVFV specific $\operatorname{IgG}$ on the day 168 when they were challenged (results not shown).

The virus neutralizing antibody responses after challenge are shown in Fig. $(\mathbf{4 A}, \mathbf{4 B})$. Immunization did not have significant effect on decreasing the development of virus neu- tralizing antibodies when compared to PBS control sheep: recNP/ISA50 (day 37, $\mathrm{p}=0.883$; day $168, \mathrm{p}=0.825$ Fisher F-test), recNP/Alhydrogel (day $37, \mathrm{p}=0.920$; day $168, \mathrm{p}=$ 0.850 ), recNP/TiterMax Gold (day 37, $\mathrm{p}=0.881$; day $168, \mathrm{p}$ $=0.975$ ) and recNP/SaponinQ (day 37, $\mathrm{p}=0.682 ;$ day $168, \mathrm{p}$ $=0.858)$.

\section{VIREMIA IN SHEEP AFTER RVFV CHALLENGE}

The viremia in sheep after RVFV challenge is shown in Table 4. Immunization of sheep did not result in significant decrease of viral loads in sera when compared to PBS control sheep. Viremia was, however, of two to four days duration whereas one PBS control sheep developed pro- 

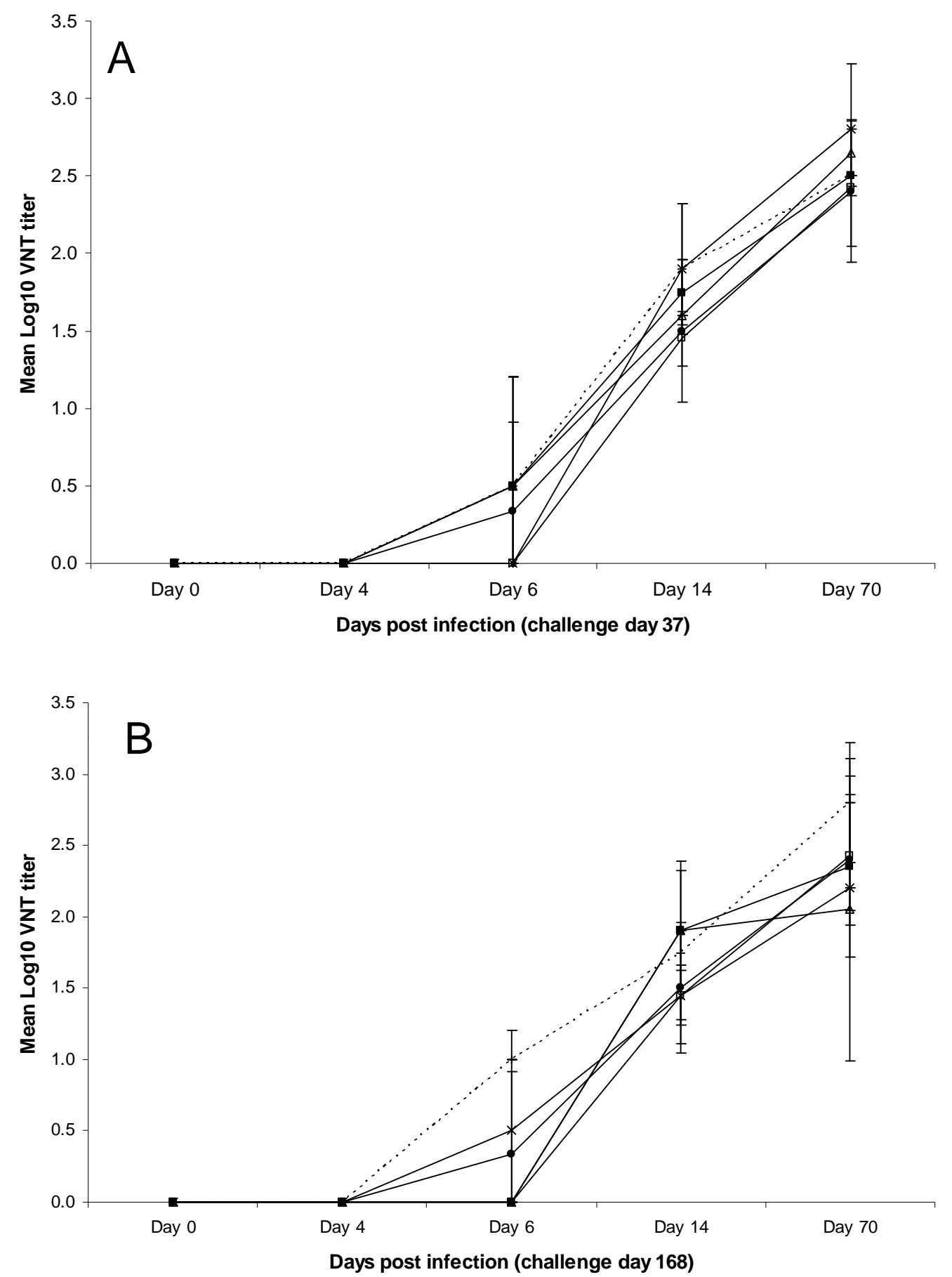

Fig. (4). Mean virus neutralizing antibody responses in sheep after RVFV challenge on day 37 (A) or 168 (B). Sheep groups are indicated as recNP/ISA50 (-----), recNP/Alhydrogel (- - -), recNP/TiterMax Gold (- - ), recNP/SaponinQ (-x-), adjuvant controls (-口-) and PBS controls (-๑). Error bars indicate standard deviations from the means of two or more sheep per group.

longed viremia up to day seven. Despite severe challenge none of the sheep, including controls, displayed any clinical signs.

\section{DISCUSSION}

There is no available RVF vaccine for humans and the currently in use live-attenuated and inactivated animal vaccines are expensive to produce and pose safety problems. Recombinant DNA technology has proven to be a useful tool for the development of alternative vaccine candidates for RVF, including recombinant subunit vaccines, recombinant attenuated virus prepared by reverse genetics, virus like particles and recombinant viruses using a non-related virus as backbone for RVF antigens. These new generation vaccines have been shown to have their distinct advantages and disadvantages, but have mostly targeted the glycoproteins of the virus which are known to induce protective neutralizing antibodies [22, 25, 27, 28]. 
Table 4. Viremia in Sheep After RVFV Challenge

\begin{tabular}{|c|c|c|c|c|}
\hline Inoculum & $\begin{array}{l}\text { Number of } \\
\text { Sheep }\end{array}$ & $\begin{array}{l}\text { Days Post } \\
\text { Infection }\end{array}$ & $\begin{array}{l}\text { Viremia } \\
\text { Mean } \log _{10} \mathrm{TCID}_{50} / \mathrm{ml} \pm \text { Standard Deviation (Range) }\end{array}$ & $\begin{array}{l}\text { Significance of Decreased } \\
\text { Viremia }^{a}\end{array}$ \\
\hline \multirow{2}{*}{$\begin{array}{l}\text { recNP/ISA50 (1a-b) } \\
(175 \text { and } 350 \mu \text { g combined) } \\
\text { Challenge day } 37 \\
\text { Challenge day } 168 \\
\end{array}$} & 2 & $\begin{array}{l}1 \\
2 \\
3 \\
4-7\end{array}$ & $\begin{array}{l}4.5 \pm 0.4(4.3 \text { to } 4.8) \\
4.4 \pm 0.2(4.3 \text { to } 4.5) \\
0.8 \pm 1.1(0.0 \text { to } 1.5) \\
\text { Negative }\end{array}$ & $\mathrm{p}=0.55$ \\
\hline & 2 & $\begin{array}{l}1 \\
2 \\
3-7\end{array}$ & $\begin{array}{l}3.6 \pm 0.5(3.3 \text { to } 4.0) \\
6.1 \pm 0.5(5.8 \text { to } 6.5) \\
2.0 \pm 1.8(0.8 \text { to } 3.3)\end{array}$ & $\mathrm{p}=0.37$ \\
\hline \multirow{2}{*}{$\begin{array}{l}\text { recNP/Alhydrogel (2a-b) } \\
(175 \text { and } 350 \mu \text { g combined) } \\
\text { Challenge day } 37 \\
\text { Challenge day } 168 \\
\end{array}$} & 2 & $\begin{array}{l}1 \\
2 \\
3 \\
4-7\end{array}$ & $\begin{array}{l}2.6 \pm 2.7(0.8 \text { to } 4.5) \\
2.0 \pm 2.8(0.0 \text { to } 4.0) \\
1.1 \pm 1.6(0.0 \text { to } 2.3) \\
\text { Negative }\end{array}$ & $\mathrm{p}=0.37$ \\
\hline & 2 & $\begin{array}{l}1 \\
2 \\
3 \\
4 \\
5-7\end{array}$ & $\begin{array}{l}3.4 \pm 0.2(3.3 \text { to } 3.5) \\
4.4 \pm 2.7(2.5 \text { to } 6.3) \\
2.4 \pm 3.4(0.0 \text { to } 4.8) \\
0.5 \pm 0.7(0.0 \text { to } 1.0) \\
\text { Negative }\end{array}$ & $\mathrm{p}=0.79$ \\
\hline \multirow{2}{*}{ 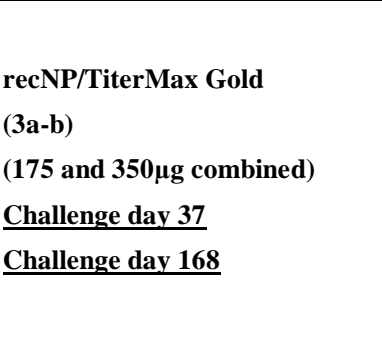 } & 2 & $\begin{array}{l}1 \\
2 \\
3-7\end{array}$ & $\begin{array}{l}4.3 \pm 1.1(3.5 \text { to } 5.0) \\
2.6 \pm 1.2(1.8 \text { to } 3.5) \\
\text { Negative }\end{array}$ & $\mathrm{p}=0.88$ \\
\hline & 2 & $\begin{array}{l}1 \\
2 \\
3 \\
4-7\end{array}$ & $\begin{array}{l}4.3 \pm 0.4(4.0 \text { to } 4.5) \\
5.0 \pm 1.1(4.3 \text { to } 5.8) \\
1.9 \pm 1.2(1.0 \text { to } 2.8) \\
\text { Negative }\end{array}$ & $\mathrm{p}=0.49$ \\
\hline \multirow{2}{*}{$\begin{array}{l}\text { recNP/SaponinQ }(4 a \\
(175 \text { and } 350 \mu \mathrm{g} \text { com } \\
\text { Challenge day } 37 \\
\text { Challenge day } 168\end{array}$} & 2 & $\begin{array}{l}1 \\
2 \\
3 \\
4-7\end{array}$ & $\begin{array}{l}4.4 \pm 0.5 \text { ( } 4.0 \text { to } 4.8) \\
4.8 \pm 0.4(4.5 \text { to } 5.0) \\
1.6 \pm 2.3(0.0 \text { to } 3.3) \\
\text { Negative }\end{array}$ & $\mathrm{p}=0.52$ \\
\hline & 2 & $\begin{array}{l}1 \\
2 \\
3 \\
4-7\end{array}$ & $\begin{array}{l}1.9 \pm 2.7(0.0 \text { to } 3.8) \\
2.0 \pm 2.8(0.0 \text { to } 4.0) \\
0.4 \pm 0.5(0.0 \text { to } 0.8) \\
\text { Negative }\end{array}$ & $\mathrm{p}=0.19$ \\
\hline $\begin{array}{l}\text { Adjuvant control } \\
\text { (ISA50, Alhydrogel, TiterMax } \\
\text { Gold and SaponinQ combined) } \\
\text { Challenge day } 37\end{array}$ & 4 & $\begin{array}{l}1 \\
2 \\
3 \\
4-7\end{array}$ & $\begin{array}{l}5.1 \pm 0.3(4.8 \text { to } 5.5) \\
4.8 \pm 1.1(3.8 \text { to } 6.0) \\
0.8 \pm 1.5(0.0 \text { to } 3.0) \\
\text { Negative }\end{array}$ & $\mathrm{p}=0.40$ \\
\hline $\begin{array}{l}\text { PBS control } \\
\text { Challenge day } 37 \text { and } 168\end{array}$ & 3 & $\begin{array}{l}1 \\
2 \\
3 \\
4 \\
5 \\
6 \\
7\end{array}$ & $\begin{array}{l}4.5 \pm 0.3 \text { ( } 4.3 \text { to } 4.8) \\
5.3 \pm 2.3 \text { (3.3 to } 7.8) \\
2.3 \pm 4.0(0.0 \text { to } 7.0) \\
1.9 \pm 3.3(0.0 \text { to } 5.8) \\
1.8 \pm 3.2(0.0 \text { to } 5.5) \\
1.5 \pm 2.6(0.0 \text { to } 4.5) \\
0.8 \pm 1.4(0.0 \text { to } 2.5)\end{array}$ & Control group \\
\hline
\end{tabular}

${ }^{a}$ Indicates the statistical significance of decrease in viral load as compared to PBS control sheep, as calculated by the Fisher F-test. P-values $\leq 0.01$ indicate a statistically significant decrease in viremia.

The nucleocapsid protein induces production of high levels of anti-NP specific IgG and IgM responses in host ani- mals $[14,15]$. It has been postulated that the strongly biased humoral antibody response to $\mathrm{N}$ protein might be a part of 
virus strategy to direct the host immune response towards viral antigenic determinants not relevant in protection [52]. On the other hand, immunization of animals with recombinant subunit $\mathrm{N}$ proteins from related bunyaviruses resulted in complete protection against viral challenge [40-42]. Immunization with a recombinant RVFV nucleocapsid protein with Quil-A adjuvant protected $60 \%$ of mice from lethal challenge [24]. Immunization of mice with cDNA encoding the $\mathrm{N}$ protein resulted in $50 \%$ protection from clinical signs after the induction of NP-specific lymphoproliferative responses [26] but the replication of challenge virus in immunized mice was not evaluated and there was $86 \%$ recovering rate in naïve mice indicating low challenge. Immunization of mice with virus like particles containing both glycoproteins and the $\mathrm{N}$ protein resulted in $92 \%$ protection [20]. This protection was most probably due to the presence of glycoproteins in the VLP since anti-NP responses could not be detected after immunization. Immunization of mice with VLPs containing the glycoproteins and NP resulted in better protection against lethal challenge when compared to those immunized with VLPs without NP [21]. Immunization of sheep with a DNA construct expressing the RVFV N protein resulted production of anti-NP antibodies but protection against RVFV challenge was never evaluated [52]. From these earlier reports it seems that the anti-NP response does play a role in protection of mice against morbidity and mortality from RVFV infection. The decrease of viral replication in these immunized mice have, however, not been evaluated yet. Vaccination against arthropod borne viruses should ideally aim to decrease morbidity and mortality, but even more importantly it should stop the spread of the virus by inducing sterilizing immunity. From the previous studies it is unclear whether NP immunization was able to decrease viral replication in challenged animals. The protective ability of the antiNP response in a host animal species, such as sheep, has never been evaluated. In this study we evaluated a recombinant subunit $\mathrm{N}$ protein of RVFV as an immunogen, in combination with four different adjuvants, in mice and measured its protective ability against RVFV challenge by using survival rates as well as decrease of viral replication after severe RVFV challenge. We also evaluated for the first time a recombinant subunit RVFV NP as an immunogen in a host animal model, sheep, and its ability to decrease viral replication in sheep after severe RVFV challenge. To our knowledge this is the first study evaluating the effect of anti-NP immunity on viral replication in both mice and a host animal species.

Four different adjuvants with differing mechanisms of enhancing immune responses were used in this study to evaluate whether this could have an effect on the level of protection against severe RVFV challenge. The RVFV recNP used was not only highly immunogenic in mice and sheep in combination with all adjuvants, but also induced a measurable response in the absence of adjuvant in mice. Even though in the limited number of mice tested at each time point there wasn't drastic differences in the strength of humoral responses in mice after immunization, there were significant differences in the level of protection against challenge. The best protection against morbidity and mortality $(100 \%)$ was achieved with 35 or $70 \mu \mathrm{g}$ of the recNP when combined with Alhydrogel adjuvant, or $70 \mu \mathrm{g}$ recNP with SaponinQ. Additionally no virus or viral RNA could be de- tected in the liver or kidney tissues from mice immunized with $70 \mu \mathrm{g}$ recNP/Alhydrogel after RVFV challenge, indicating possible sterilizing immunity. Alhydrogel, more commonly known as alum, promote the release of IL-4 which results in the increased expression of MHC-II molecules on monocytes, consequently increasing antigen uptake by antigen presenting cells (APC) [36, 37]. Alum also activates NF$\kappa \mathrm{B}$, a protein complex found in almost all cell types and that is involved in regulating the cellular response to infections by effecting positive selection of memory $\mathrm{CD} 8^{+} \mathrm{T}$ cells [3739]. This is the first study showing $100 \%$ protection from morbidity and mortality and viral replication in mice immunized with a RVFV subunit nucleocapsid protein after severe RVFV challenge, and confirms previous findings that the anti-NP response does play a role in protecting mice from RVFV challenge [20, 21, 24, 26]

Other recNP/adjuvant combinations were not as effective as Alhydrogel in inducing protective and sterilizing immunity. The mice immunized with $70 \mu \mathrm{g}$ recNP/SaponinQ was also $100 \%$ protected from morbidity/mortality but replicating virus or viral RNA was found in the organ tissues of some of the mice in this group. The lower dose of the recNP/SaponinQ combination was less effective and resulted in protection of only $67 \%$ of mice from morbidity/mortality while virus still replicated in their organs. Saponins modulate humoral (Th-2) as well as cellular immunity, but seem to be more effective via the Th-1 cellular route and can induce strong CD8+ cytotoxic T-cell responses [34]. The two adjuvants that enhance immune responses by very similar mechanisms, ISA50 and TiterMax Gold, were equally ineffective in inducing significant protective and sterilizing immunity in mice after RVFV challenge. These two adjuvants induce mixed Th-1/Th- 2 responses, but responses are usually biased towards Th-2 which is indicative of a stronger humoral response [29, 33, 53]. The worst protected immunized mice were those in the group immunized only with recNP and no adjuvant. Our findings emphasize the importance of an adjuvant in modulating a desired protective immune response to a specific antigen.

Irrespective of the dose used all recNP/adjuvant combinations were highly immunogenic in sheep even after a single immunization. Anti-NP IgG responses in immunized sheep were equal to or higher than the level of anti-NP antibodies in experimentally infected sheep. After RVFV challenge the control sheep developed strong IgM response, which in immunized sheep was much weaker, but still detectable after challenge. Although these results might have indicated lower virus replication in immunized sheep after challenge; surprisingly there were no significant differences in the virus neutralizing titres in immunized sheep when compared to control sheep. Also, humoral immunity against the NP was not able to significantly decrease viremia when compared to control sheep.

The results of the study demonstrate that sterilizing immunity could be induced with a recombinant subunit RVFV nucleocapsid protein in a mouse model when used with specific adjuvants, but the same recNP/adjuvant combinations were not able to induce the same level of immunity in a ruminant host species. Our findings highlight also some important aspects that should be considered for future research and development of vaccine candidates for RVF. Firstly the anti- 
nucleocapsid response alone, although protective in mice, does not seem to play a role in protection of an actual host species against RVFV infection. Secondly, our results show that mice might not be the best animal model for studying protective ability of RVF vaccines. Although the target proteins of choice for RVFV vaccines are glycoproteins because of inducing neutralizing antibody, RVFV vaccine candidates targeting the glycoproteins which were evaluated in mice have also yielded inconsistent protection against challenge $[20,21,23]$. In a recent study it was shown that immunization with VLPs combining the glycoproteins and nucleocapsid protein yielded better protection [21]. Therefore it appears that vaccine candidates combining glyco- and nucleocapsid proteins should be further investigated.

\section{ETHICS CLEARANCES}

Ethics clearances for the use of animals were obtained from the National Health Laboratory Service Animal Ethics Committee (NHLS AEC 109/07) and the University of the Witwatersrand Animal Ethics Screening Committee (AESC 2008/16/4).

\section{CONFLICT OF INTEREST}

The authors declare that there is no conflict of interest.

\section{ACKNOWLEDGEMENTS}

This work was supported by the Poliomyelitis Research Foundation (PRF Grant number 08/14). We would like to thank the South African Vaccine Producers (SAVP) for supplying the mice and sheep, and husbandry during the prechallenge phase of the experiment. Caroline T. Tiemessen is a Welcome Trust International Senior Research Fellow (076352/Z/05/Z).

\section{REFERENCES}

[1] Swanepoel, R.; Coetzer, J.A.W. Rift Valley fever. In Infectious Diseases of Livestock, Coetzer, J. A. W., Tustin, R.C., Eds. Oxford University Press: Cape Town, 2004; Vol. 2, pp. 1037-1070.

[2] Woods, C.W.; Karpati, A.M.; Grein, T.; McCarthy, N.; Gaturuku, P.; Muchiri, E.; Dunster, L.; Henderson, A.; Khan, A.S.; Swanepoel, R.; Bonmarin, I.; Martin, L.; Mann, P.; Smoak, B.L.; Ryan, M.; Ksiazek, T.G.; Arthur, R.R.; Ndikuyeze, A.; Agata, N.N.; Peters, C.J. An outbreak of Rift Valley fever in Northeastern Kenya, 1997-98. Emerg. Infect. Dis., 2002, 8(2), 138-144.

[3] Bishop, D.H.; Calisher, C.H.; Casals, J.; Chumakov, M.P.; Gaidamovich, S.Y.; Hannoun, C.; Lvov, D.K.; Marshall, I.D.; OkerBlom, N.; Pettersson, R.F.; Porterfield, J.S.; Russell, P.K.; Shope, R.E.; Westaway, E.G. Bunyaviridae. Intervirology, 1980, 14, 125143.

[4] Gargan, T.P., 2nd; Clark, G.G.; Dohm, D.J.; Turell, M.J.; Bailey, C.L. Vector potential of selected North American mosquito species for Rift Valley fever virus. Am. J. Trop. Med. Hyg., 1988, 38(2), 440-6.

[5] Turell, M.J.; Dohm, D.J.; Mores, C.N.; Terracina, L.; Wallette, D.L., Jr.; Hribar, L.J.; Pecor, J.E.; Blow, J.A. Potential for North American mosquitoes to transmit Rift Valley fever virus. J. Am. Mosq. Control Assoc., 2008, 24(4), 502-507.

[6] Turell, M.J.; Lee, J.S.; Richardson, J.H.; Sang, R.C.; Kioko, E.N.; Agawo, M.O.; Pecor, J.; O'Guinn, M.L. Vector competence of Kenyan Culex zombaensis and Culex quinquefasciatus mosquitoes for Rift Valley fever virus. J. Am. Mosq. Control Assoc., 2007, 23(4), 378-382.

[7] Turell, M.J.; Linthicum, K.J.; Patrican, L.A.; Davies, F.G.; Kairo, A.; Bailey, C.L. Vector competence of selected African mosquito (Diptera: Culicidae) species for Rift Valley fever virus. J. Med. Entomol., 2008, 45(1), 102-108.
[8] Giorgi, C.; Accardi, L.; Nicoletti, L.; Gro, M.C.; Takehara, K.; Hilditch, C.; Morikawa, S.; Bishop, D.H. Sequences and coding strategies of the S RNAs of Toscana and Rift Valley fever viruses compared to those of Punta Toro, Sicilian Sandfly fever, and Uukuniemi viruses. Virology, 1991, 180(2), 738-753.

[9] Ihara, T.; Akashi, H.; Bishop, D.H. Novel coding strategy (ambisense genomic RNA) revealed by sequence analyses of Punta Toro Phlebovirus S RNA. Virology, 1984, 136(2), 293-306.

[10] Magurano, F.; Nicoletti, L. Humoral response in Toscana virus acute neurologic disease investigated by viral-protein-specific immunoassays. Clin. Diagn. Lab. Immunol., 1999, 6(1), 55-60.

[11] Schwarz, T.F. Imported vector- and rodent-borne virus infections-an introduction. Arch. Virol. Suppl., 1996, 11, 3-11.

[12] Swanepoel, R.; Struthers, J.K.; Erasmus, M.J.; Shepherd, S.P.; McGillivray, G.M.; Shepherd, A.J.; Hummitzsch, D.E.; Erasmus, B.J.; Barnard, B.J. Comparative pathogenicity and antigenic crossreactivity of Rift Valley fever and other African phleboviruses in sheep. J. Hyg (Lond.), 1986, 97(2), 331-346.

[13] Vapalahti, O.; Kallio-Kokko, H.; Narvanen, A.; Julkunen, I.; Lundkvist, A.; Plyusnin, A.; Lehvaslaiho, H.; BrummerKorvenkontio, M.; Vaheri, A.; Lankinen, H. Human B-cell epitopes of Puumala virus nucleocapsid protein, the major antigen in early serological response. J. Med. Virol., 1995, 46, 293-303.

[14] Fafetine, J.M.; Tijhaar, E.; Paweska, J.T.; Neves, L.C.; Hendriks, J.; Swanepoel, R.; Coetzer, J.A.; Egberink, H.F.; Rutten, V.P. Cloning and expression of Rift Valley fever virus nucleocapsid (N) protein and evaluation of a N-protein based indirect ELISA for the detection of specific IgG and IgM antibodies in domestic ruminants. Vet. Microbiol., 2007, 121(1-2), 29-38.

[15] Jansen van Vuren, P.; Potgieter, A.C.; Paweska, J.T.; van Dijk, A.A. Preparation and evaluation of a recombinant Rift Valley fever virus $\mathrm{N}$ protein for the detection of $\operatorname{IgG}$ and $\operatorname{IgM}$ antibodies in humans and animals by indirect ELISA. J. Virol. Methods, 2007, 140(1-2), 106-114.

[16] Barnard, B.J. Rift Valley fever vaccine--antibody and immune response in cattle to a live and an inactivated vaccine. J. S. Afr. Vet. Assoc., 1979, 50(3), 155-157.

[17] Hunter, P.; Erasmus, B.J.; Vorster, J.H. Teratogenicity of a mutagenised Rift Valley fever virus (MVP 12) in sheep. Onderstepoort J. Vet. Res., 2002, 69(1), 95-98.

[18] Muller, R.; Saluzzo, J.F.; Lopez, N.; Dreier, T.; Turell, M.; Smith, J.; Bouloy, M. Characterization of clone 13, a naturally attenuated avirulent isolate of Rift Valley fever virus, which is altered in the small segment. Am J. Trop. Med. Hyg., 1995, 53(4), 405-411.

[19] Bird, B.H.; Albarino, C.G.; Hartman, A.L.; Erickson, B.R.; Ksiazek, T.G.; Nichol, S.T. Rift valley fever virus lacking the NSs and NSm genes is highly attenuated, confers protective immunity from virulent virus challenge, and allows for differential identification of infected and vaccinated animals. J. Virol., 2008, 82(6), 2681-2691.

[20] Naslund, J.; Lagerqvist, N.; Habjan, M.; Lundkvist, A.; Evander, M.; Ahlm, C.; Weber, F.; Bucht, G. Vaccination with virus-like particles protects mice from lethal infection of Rift Valley Fever Virus. Virology, 2009, 385(2), 409-415.

[21] Mandell, R.B.; Koukuntla, R.; Mogler, L.J.; Carzoli, A.K.; Freiberg, A.N.; Holbrook, M.R.; Martin, B.K.; Staplin, W.R.; Vahanian, N.N.; Link, C.J.; Flick, R. A replication-incompetent Rift Valley fever vaccine: Chimeric virus-like particles protect mice and rats against lethal challenge. Virology, 2010, 397(1), 187-198.

[22] Collett, M.S.; Keegan, K.; Hu, S.L.; Sridhar, P.; Purchio, A.F.; Ennis, W.H.; Dalrymple, J.M. Protective Subunit Immunogens to Rift Valley Fever Virus from Bacteria and Recombinant Vaccinia Virus. In The Biology of Negative Strand Viruses, Mahy, B., Kolakofsky, D., Eds. Elsevier: New York, 1987; Vol. 43, pp. 321 329.

[23] Heise, M.T.; Whitmore, A.; Thompson, J.; Parsons, M.; Grobbelaar, A.A.; Kemp, A.; Paweska, J.T.; Madric, K.; White, L.J.; Swanepoel, R.; Burt, F.J. An alphavirus replicon-derived candidate vaccine against Rift Valley fever virus. Epidemiol. Infect., 2009, 137(9), 1309-1318.

[24] Wallace, D.B.; Ellis, C.E.; Espach, A.; Smith, S.J.; Greyling, R.R.; Viljoen, G.J. Protective immune responses induced by different recombinant vaccine regimes to Rift Valley fever. Vaccine, 2006, 24(49-50), 7181-7189.

[25] Wallace, D.B.; Viljoen, G.J. Immune responses to recombinants of the South African vaccine strain of lumpy skin disease virus gene- 
rated by using thymidine kinase gene insertion. Vaccine, 2005, 23(23), 3061-3067.

[26] Lagerqvist, N.; Naslund, J.; Lundkvist, A.; Bouloy, M.; Ahlm, C.; Bucht, G. Characterisation of immune responses and protective efficacy in mice after immunisation with Rift Valley Fever virus cDNA constructs. Virol. J., 2009, 6, 6.

[27] Spik, K.; Shurtleff, A.; McElroy, A.K.; Guttieri, M.C.; Hooper, J.W.; SchmalJohn, C. Immunogenicity of combination DNA vaccines for Rift Valley fever virus, tick-borne encephalitis virus, Hantaan virus, and Crimean Congo hemorrhagic fever virus. Vaccine, 2006, 24(21), 4657-4666.

[28] Schmaljohn, C.S.; Parker, M.D.; Ennis, W.H.; Dalrymple, J.M.; Collett, M.S.; Suzich, J.A.; Schmaljohn, A.L. Baculovirus expression of the M genome segment of Rift Valley fever virus and examination of antigenic and immunogenic properties of the expressed proteins. Virology, 1989, 170(1), 184-192.

[29] O'Hagan, D.T.; MacKichan, M.L.; Singh, M. Recent developments in adjuvants for vaccines against infectious diseases. Biomol. Eng., 2001, 18(3), 69-85.

[30] Singh, M.; O'Hagan, D. Advances in vaccine adjuvants. Nat. Biotechnol., 1999, 17(11), 1075-1081.

[31] Dasgupta, A. Targeting TFIIH to inhibit host cell transcription by Rift Valley Fever Virus. Mol. Cell, 2004, 13(4), 456-458.

[32] Kensil, C.R.; Mo, A.X.; Truneh, A. Current vaccine adjuvants: an overview of a diverse class. Front. Biosci., 2004, 9, 2972-2988.

[33] Cribbs, D.H.; Ghochikyan, A.; Vasilevko, V.; Tran, M.; Petrushina, I.; Sadzikava, N.; Babikyan, D.; Kesslak, P.; Kieber-Emmons, T.; Cotman, C.W.; Agadjanyan, M.G. Adjuvant-dependent modulation of Th1 and Th2 responses to immunization with beta-amyloid. Int. Immunol., 2003, 15(4), 505-514.

[34] Kensil, C.R. Saponins as vaccine adjuvants. Crit. Rev. Ther. Drug Carrier Syst., 1996, 13(1-2), 1-55.

[35] Xu, F.; Liu, D.; Nunes, M.R.; da Rosa, A.P.; Tesh, R.B.; Xiao, S.Y. Antigenic and genetic relationships among Rift Valley fever virus and other selected members of the genus Phlebovirus (Bunyaviridae). Am. J. Trop. Med. Hyg., 2007, 76(6), 1194-1200.

[36] Mannhalter, J.W.; Neychev, H.O.; Zlabinger, G.J.; Ahmad, R.; Eibl, M.M. Modulation of the human immune response by the nontoxic and non-pyrogenic adjuvant aluminium hydroxide: effect on antigen uptake and antigen presentation. Clin. Exp. Immunol., 1985, 61, 143-151.

[37] Ulanova, M.; Tarkowski, A.; Hahn-Zoric, M.; Hanson, L.A. The common vaccine adjuvant aluminum hydroxide up-regulates accessory properties of human monocytes via an interleukin-4-dependent mechanism. Infect. Immun., 2001, 69(2), 1151-1159.

[38] Hettmann, T.; Leiden, J.M. NF- $\mathrm{BB}$ is required for the positive selection of CD8+ thymocytes. J. Immun., 2000, 165, 5004-5010.

[39] Hettmann, T.; Opferman, J.T.; Leiden, J.M.; Ashton-Rickardt, P.G. A critical role for NF-kappaB transcription factors in the development of CD8+ memory-phenotype T cells. Immun. Lett., 2003, 85(3), 297-300.

[40] Maes, P.; Clement, J.; Cauwe, B.; Bonnet, V.; Keyaerts, E.; Robert, A.; Van Ranst, M. Truncated recombinant puumala virus nucleocapsid proteins protect mice against challenge in vivo. Viral Iтmиnol., 2008, 2l(1), 49-60.
[41] Maes, P.; Keyaerts, E.; Bonnet, V.; Clement, J.; Avsic-Zupanc, T.; Robert, A.; Van Ranst, M. Truncated recombinant Dobrava hantavirus nucleocapsid proteins induce strong, long-lasting immune responses in mice. Intervirology, 2006, 49(5), 253-260.

[42] Schmaljohn, C.S.; Chu, Y.K.; Schmaljohn, A.L.; Dalrymple, J.M. Antigenic subunits of Hantaan virus expressed by baculovirus and vaccinia virus recombinants. J. Virol., 1990, 64(7), 3162-3170.

[43] Jansen van Vuren, P.; Paweska, J.T. Laboratory safe detection of nucleocapsid protein of Rift Valley fever virus in human and animal specimens by a sandwich ELISA. J. Virol. Methods, 2009, 157(1), 15-24.

[44] Paweska, J.T.; Jansen van Vuren, P.; Swanepoel, R. Validation of an indirect ELISA based on a recombinant nucleocapsid protein of Rift Valley fever virus for the detection of IgG antibody in humans. J. Virol. Methods, 2007, 146(1-2), 119-124.

[45] Evans, A.; Gakuya, F.; Paweska, J.T.; Rostal, M.; Akoolo, L.; Van Vuren, P.J.; Manyibe, T.; Macharia, J.M.; Ksiazek, T.G.; Feikin, D.R.; Breiman, R.F.; Njenga, K.M. Prevalence of antibodies against Rift Valley fever virus in Kenyan wildlife. Epidemiol. Infect., 2008, 136(9), 1261-1269.

[46] Paweska, J.T.; van Vuren, P.J.; Kemp, A.; Buss, P.; Bengis, R.G.; Gakuya, F.; Breiman, R.F.; Njenga, K.M.; Swanepoel, R. Recombinant nucleocapsid-based ELISA for detection of IgG antibody to Rift Valley fever virus in African buffalo. Vet. Microbiol., 2008, 127(1-2), 21-28.

[47] Anonymous. Rift Valley fever outbreak--Kenya, November 2006January 2007. MMWR Morb. Mortal Wkly. Rep., 2007, 56(4), 7376.

[48] Paweska, J.T.; Burt, F.J.; Anthony, F.; Smith, S.J.; Grobbelaar, A.A.; Croft, J.E.; Ksiazek, T.G.; Swanepoel, R. IgG-sandwich and IgM-capture enzyme-linked immunosorbent assay for the detection of antibody to Rift Valley fever virus in domestic ruminants. $J$. Virol. Methods, 2003, 113(2), 103-12.

[49] Le Roux, C.A.; Kubo, T.; Grobbelaar, A.A.; van Vuren, P.J.; Weyer, J.; Nel, L.H.; Swanepoel, R.; Morita, K.; Paweska, J.T. Development and evaluation of a real-time reverse transcriptionloop-mediated isothermal amplification assay for rapid detection of Rift Valley fever virus in clinical specimens. J. Clin. Microbiol., 2009, 47(3), 645-51.

[50] Kärber, G. Beitrag zur kollectiven Behandlung pharmakologischer Reihensversuche. Arch. Exp. Pathol. Pharm., 1931, 162, 480-483.

[51] Soper, D.S., The free statistics calculators website. 2009 http:// www.danielsoper.com/statcalc/

[52] Lorenzo, G.; Martin-Folgar, R.; Rodriguez, F.; Brun, A. Priming with DNA plasmids encoding the nucleocapsid protein and glycoprotein precursors from Rift Valley fever virus accelerates the immune responses induced by an attenuated vaccine in sheep. Vaccine, 2008, 26(41), 5255-5262.

[53] Berhanu, A.; Wilson, R.L.; Kirkwood-Watts, D.L.; King, D.S.; Warren, T.K.; Lund, S.A.; Brown, L.L.; Krupkin, A.K.; Vandermay, E.; Weimers, W.; Honeychurch, K.M.; Grosenbach, D.W.; Jones, K.F.; Hruby, D.E. Vaccination of BALB/c mice with Escherichia coli-expressed vaccinia virus proteins A27L, B5R, and D8L protects mice from lethal vaccinia virus challenge. J. Virol., 2008, 82(7), 3517-3529. 